\title{
NEIGHBOURS' RIGHTS AND ABUSE OF RIGHTS ${ }^{* *}$
}

\begin{abstract}
The subject matter of this paper is the analysis of the ownership right and its limitations in neighbour-law relationships, including the restrictions on ownership and neighbours' rights due to the prohibition of abuse of rights. Neighbours' rights set boundaries to the content of the ownership right, whereas the prohibition of abuse of rights additionally restricts the freedom of exercising the recognised content of the ownership right. The paper aims to point out to the basic differences between neighbours' rights and the prohibition of abuse of rights, as well as to the occasional overlapping of their legal functions and effects.
\end{abstract}

Key words: ownership, neighbours' rights, abuse of rights.

\section{Introduction}

Ownership is a socially regulated way of appropriating things (assets) which provides for satisfying the most diverse human needs, including both the primary (biological and physiological) needs and the derived "cultural" ones (psychological, spiritual, aesthetic, conventional, luxury-oriented, etc) (Gams, 1991: 12). Considering that ownership is the basic facet of life, freedom, power [...], it has always represented the object of the greatest factual and legal protection.

\footnotetext{
*lazic@prafak.ni.ac.rs

** This paper is the result of research supported by the Ministry of Education, Science and Technological Development of the Republic of Serbia (Agreement no. 451-03-68/202014/200120).
} 
The notion of ownership (Lat. dominium proprietas), as an individual, absolute and exclusive right, may be traced back to Roman $\operatorname{Law}^{1}$, but it received its full confirmation in the period of liberal capitalism and the first civil bourgeois $\operatorname{codes}^{2}$. Those codes treated property as a natural and eternal (imprescriptible) right of $\operatorname{man}^{3}$.

Yet, freedom of an owner, particularly over immovable property (such as land and buildings), is necessarily limited by equivalent freedom of another owner. Thus, besides explicitly defining the content of the ownership right. legislators have always imposed some restrictions, pertaining to public and private ownership alike (Stojanović, 1987:80; Kovačević Kuštrimović, Lazić, 2008:73). Ownership seems to have always been "a progeny of its own time" (Stojanović, 1991:1176). Yet, given that the essential feature of ownership as an individual (sovereign) right is increasingly compromised ${ }^{4}$, it has become a social category that is increasingly narrowed down in favour of a general social interest. Thus, owners are subjected to different legal and social restrictions, including both the explicit legal restrictions (e.g. on neighbours' rights) and the ones relying by virtue of law on the social morale (e.g. the prohibition of abuse of rights when exercising ownership powers, as well as those stemming from neighbours' rights). The subject matter of consideration in this paper are the restrictions pertaining to the content of ownership which is restricted by neighbours' rights and the manner of exercising ownership.

\section{The Ownership Right and Neighbour-Law Restrictions}

The relationship between neighbours is a complex social relationship entailing a set of different human interests and behaviours arising from the clash of two ownership rights over real estates. Given that customary law alone cannot

1 Qui suo iure utitur, neminem laedit (Dicta, Sec. Paulus - D. 50, 17, 155). "He who uses his own right harms no one" (Stojčević, Romac, 1984: 434, 325).

2 "Ownership is the right to enjoy and dispose of things in the most absolute manner, provided they are not used in a way prohibited by statutes or regulations" (Art. 544 of the French Code Civil). A similar definition exists in $\S 354$ of the Austrian Civil Code/ABGB; $\S 903$ of the German Civil Code/BGB; $\S \S 211$ and 216 of the Civil Code of the Principality of Serbia (1844); and Art. 93 of the General Property Code of the Principality of Montenegro (1888).

3 Article 2 of the French Declaration of the Rights of Man and the Citizen (1789) envisaged: "The goal of any political association is the preservation of the natural and imprescriptible rights of man. These rights are liberty, property, safety and resistance against oppression."

4 The notion of ownership as an individual (sovereign) right is also an expression of the general understanding of the specific time and society, rather than a permanently acquired developmental value of the ownership right. The rule Uti, non abuti (Ulpianus - D.7,1,15,1), meaning "to use, not to abuse", has always been an integral part of the concept of ownership. 
adequately regulate numerous neighbours relationships, the "law" (statutory legislation) had to respond and regulate these issues by relevant legal provisions. Thus, neighbours' relationship has become either a conceptual element of certain legal institutes (the regulation of boundary lines, neighbours' rights, the pre-emption right to purchase the adjacent agricultural land, etc.) or an element of factual circumstances (e.g. trespass to property, disturbance of possession, retention rights, compensation for damage, etc.) Consequently, neighbour law regulates only one aspect of neighbours' relations arising from the restriction of ownership.

The limitation of the ownership right content (imposed on the owner as a selfcentred individual) was performed in the interest of the owner as a social being. After the First World War, the social character of ownership prevailed (Savić, 2012: 233). "Property obligates. Its use is to be at the same time service for the best good of the public" (Art. 153 para.3, Weimar Constitution). ${ }^{5}$ However, the first limitations of the ownership right contents occurred much earlier, with the emergences of ownership rights, and these limitations primarily referred to neighbours' rights. "Our legal powers are not abstract; they have a social value; as such, they have to be exercised in a social context, in compliance with the goal that is changeable in different countries, times and legal relationships at issue, but that goal [...]makes the essence of our rights [...]" (Marković, 1978:1008).

Neighbour law is a specific legal limitation of ownership in private interest which ensues alongside with the ownership right, but the justification for the expansion of neighbours' rights is the frequent abuse of ownership. The abuse of rights originally emerged in neighbour-law relations pertaining to ownership over land, but it subsequently developed into a separate legal institute regulating a specific form of limitation in exercising the established content of the ownership right.

"Neighbour rights exist over the adjacent real estates whose use is interdependent because, according to local customs, they are deemed to be neighbouring properties" (Toroman, 1978:234). Neighbours' rights imply the power of the owner of one real estate to make use of the neighbouring real estate, or to request from the owner of the neighbouring real estate to take a specific action or to abstain from exercising a specific ownership power. It is a legal limitation of ownership that is introduced in the mutual interest of the owners of neighbouring estates (praedia vicina) for the purpose of preserving good neighbourly relations, but also in the general interest of preventing any confrontation of the real estate owners.

5 Art. 153 para. 3 of the Weimar Constitution, 1919 (Savić, 2012: 227-234). 
The first neighbours' rights emerged in conjunction with ownership over real estate (e.g. boundary lines). Boundary lines are the key conceptual element of ownership, given that there is no ownership over land without the explicit demarcation of the subject matter of ownership. A more intensive development of neighbours' rights was the result of modern-day disputes over ownership, particularly in urban areas where a large number of people live in a relatively small space.

Neighbour-law limitations are legal restrictions aimed at accomplishing three goals: the reciprocity of neighbours' rights and obligations, the prohibition of causing disturbance to the neighbouring property, and the correlation of neighbours' rights and obligations. In legal theory, they are commonly classified into three groups:

1) neighbours' rights that prohibit causing disturbance to neighbours in their quiet and rational use of their real estate (the right to protection against digging beneath the ground jeopardising the stability of neighbouring buildings, protection against changing the natural water flow, and protection against emissions (private nuisance);

2) neighbours' rights characterised by the reciprocity of neighbours' rights and obligations (mutual use of the common fence, boundary lines, hedges, walls, etc.);

3) neighbours' rights characterised by the correlation of neighbours' rights and obligations; they are similar to easements and refer to the right to use the neighbouring land and the right of way (Toroman, 1978:235; Stojanović, 1991:121; Kovačević-Kuštrimović, Lazić, 2009:75).

The neighbours' rights in the second and third category are quite prone to being abused as they provide specific powers to the holders of these rights.

\section{Prohibition of Abuse of Ownership Rights}

Although Roman law did not recognize the institute of prohibition of abuse of rights, which is often disputed by many Roman law scholars (Jovanović, 1996:100), the concept Malitis non est indulgendum ("Malice is not to be indulged") may be traced back to Roman law ${ }^{6}$ (Stojčević, Romac, 1984: 274). However, the prevalent rule in Roman law was: Qui suo iure utitur, neminem laedit ("He who exercises his legal rights harms no one") (Stojčević, Romac, 1984:434).7

Konstantinović (1925) noted that "it is a misconception that the prohibition of abuse of rights is of recent origin and that individualism and prohibition of

6 Celsus -D. 6,1,38. Dicta et regulae iuris (Stojčević, Romac, 1984:274, no. 69).

7 Sec. Paulus - D. 50, 17, 155, 1. Dicta (Stojčević, Romac, 1984:434, no. 325). 
abuse of rights mutually exclude each other" (Anali PF u Beogradu, 1982:269). ${ }^{8}$ However, the theory of abuse of rights started to take form in French law in the $19^{\text {th }}$ century, on the basis of judicial decisions (case law), as a result of the growing understanding that the exercise of the ownership right must move not only within the limits set by the positive (objective) law, primarily by statutory legislation, but also in accordance with the purpose and the spirit of law, i.e. the social morality. This issue was first regulated in the German Civil Code $(\S 226$ $\mathrm{BGB}$, amended in $\S 826){ }^{9}$

Konstantinović (1925) also noted that "the prohibition of abuse means a very simple thing. Anyone who has exercised one's own right only out of malice to the injured party, with the intention to cause damage, and, generally, every one who has exercised one's right without malicious intention but in an abnormal manner, thus causing damage to another person and preventing the other person to exercise his own right in a normal manner, shall be held liable for inflicting damage." (Anali PF u Beogradu, 1982:269).

Long ago, the population growth and modernisation of life "extinguished the notion of ownership as an individual (sovereign) right, i.e. its concept of ownership as a "fortress where it is forbidden to ask "how" and "why" something is done" (Rodier, 1960:7); the new limitations to ownership seem to be gradually turning into reality Rodier's prediction on "imminent disappearance of the purported absolute rights" (Rodier, 1960:7).

It is most difficult to determine the criterion for establishing the existence of abuse of rights, i.e. to distinguish between the permissible "use" and the impermissible use (abuse) of rights. Given that human creativity is inexhaustible (both in positive and negative terms), the first legal reactions to the malicious abuse of rights and the first legal criteria were developed in judicial practice (case law).

First of all, the judicial practice may dispute and bar the legally valid rights which have been exercised with the aim of inflicting damage to another (chicanery as a form of abuse of rights). ${ }^{10}$ It is the so-called narrow (subjective) concept of abuse of rights. "Rights are social prerogatives intended for accomplishing

8 M. Konstantinović (1925). Zabrana zloupotrebe prava i socijalizacija prava (Prohibition of abuse of rights and socialisation of law), Arhiv za pravne i društvene nauke, Beograd, 3/1925, reprinted in Anali Pravnog fakulteta u Beogradu, 1982, vol. 30. br. 3-4 (261-281)

9 Notably, the General Property Code (GPC) of the Principality of Montenegro (1888) regulated the prohibition of abuse of rights a bit earlier, but V. Bogišić transposed this legal institute from German and French legal theory and practice. "You cannot exercise your right just to harm or disturb anyone (art. $1000 \mathrm{GPC}$ ); " Do not indulge in hair-splitting in your own right”. (art. 1014 GPC) (Bogišić, 1898, in: Danilovic, 1998: 276, 277).

10 "When a right is intended to be exercised for its own sake, irrespective of its moral or at least utilitarian goals alone, it is called a chicane" (Radbruch, 1980:135). 
social peace and a fair balance of interest in disputes; therefore, they must not be put into the service of malice; any deliberate act committed with intent to inflict harm to another cannot enjoy legal protection" (Marković, 1978:1009). As a legal institute, the abuse of rights emerged in the process of evolution of responsibility which imposed the need to recognise that "the rights are not granted to individuals by public authorities to exercise them arbitrarily, as they wish, but rather to exercise them for a specific purpose; created by the society, they also have a social task: a specific purpose and a specific goal which they cannot be and must not be separated from" (Joserand, 1935:328).

Further development of legal theory on the abuse of rights generated the broader concept, embodied in the so-called "ultimate goal" (objective) criterion. According to this conception, abuse exists where the subjective (individual) right is exercised contrary to the ultimate goal for which it is established. It may involve a lack of interest in the exercise of rights, a disturbance of the balance of interests, an abnormal exercise of rights, diverting the right from the designated function (social and economic goals), failure to exercise the right in a prudent manner, inadequate and disproportionate exercise of rights, etc. These are the sub-criteria developed by judicial practice for assessing the abuse of rights.

The institute of the prohibition of abuse of rights is widely accepted in contemporary law. It is a consequence of the fact that "subjective rights are not exercised in a vacuum but in a social environment; an individual is only one of its numerous cells; consequently, when an individual exercises his/her subjective rights, he/she simultaneously contributes to accomplishing a social function" (Marković, 1978:1005).

The Serbian law has adopted the broader (objective) concept of abuse of rights. "The owner shall exercise the right of ownership in accordance with the nature and purpose of the property asset. Exercising the ownership right contrary to the goal for which it has been established or recognised by the law shall be forbidden" (Art. $4^{11}$ In comparative law, the legal standard of "good practice" is a common method for preventing the abuse of rights.

The prohibition of abuse of rights was initially established in relation to the exercise of the ownership right as the broadest absolute civil subjective right, and its application was subsequently extended to other civil subjective rights.

11 Art. 4 of the Ownership and Real Property Relations Act, Official Gazette of the SFRY no.6 /1980, 36/1990; "Official Gazette of the FRY" no. 29/1996, and "Official Gazette of the $R S^{\prime \prime}$, no. $115 / 2005$-other law. 


\section{Delimitation of Neighbours' Rights and Abuse of Rights}

Neighbours' rights imply a legal restriction of the content of the ownership right which narrows down the owner's powers and renders any non-compliance an impermissible and illegal act. In relation to a breach of neighbours' rights, the court issues a judgement of declarative character. The abuse of ownership rights entails the performance of ownership-related powers in the manner that is prohibited by the positive (objective) law because the act is abusive in terms of the goal of performance, or the manner of performance. The abuse of rights does not entail a direct restriction of the content of ownership but of the manner of its performance, which imposes an additional obligation on the owner - the obligation to exercise the right in a civilised (considerate) manner (civiliter modo). It arises from the need for moralisation and socialisation of rights. Konstantinović (1925) noted that "the prohibition of abuse of rights has its basis in the general need for the greatest possible peace and security in each social community. It is a legal rule as much as a moral one (Anali PF u Beogradu, 1982:73; Lazarević, 1960:43).

Neighbours' rights entail a direct and concrete legal restriction of the content of the ownership right, while the abuse of rights entails a direct and general legal restriction of the manner of performing ownership powers. The abuse of rights institute enables the law to follow the dynamics of social life, and the law is put into effect by applying legal standards by a court-of-law, in accordance with local customs and circumstances of exercising ownership rights.

The neighbour-law restriction of ownership may be preceded by a specific abuse of the ownership right. For instance, opening windows on one's own building which are facing towards the neighbour's building is a permissible exercise of the ownership right which arises from the ownership powers on the use of things (ius utendi). Consequently, in our judicial practice (case law), it is deemed that "there is no disturbance when the owner makes an opening in his/her fence or opens a window in his/her aerial space and gets a view of the neighbour's yard." ${ }^{12}$ However, "opening a window towards the neighbour's yard should be carried out in such a manner that it causes the least possible disturbance to the neighbour's ownership right; otherwise, it may constitute an abuse of rights." ${ }^{13}$

The abuse of the ownership power to open a window on one's building is the condition for the restriction of this right, by enacting a set of the urban-planning regulations which prescribe the conditions for opening windows towards the

12 Збирка судских одлука (Collection of Court Decisions), Beograd, 1969, book 14, vol. 2, Decision no. 155

13 Odluka Višeg suda Vojvodine (Decision of the Higher Court of Vojvodina), Rev. 524/87, Судска пракса (Court Case Law), Beograd, 10/1988, Decision no. 55 
neighbouring estates. These regulations have a character of neighbour-law restrictions that narrow down the abuse of the ownership right related to opening windows; but, does it completely exclude the abuse of rights? The answer lies in shaping the owner's prospective conduct within the limits of these regulations. "Where the "law" explicitly prohibiting specific behaviour enters the "scene", the abuse of rights disappears as a stream sinking into subterranean watercourses, and unexpectedly springs out in another area" (Kovačević Kuštrimović, 1996: 17).

In terms of their legal nature, both the violation of neighbours' rights and the abuse of ownership rights are impermissible behaviour. In the former case, there is an explicit unlawful behaviour, and the consequences are eliminated by restoring the previous condition and seeking compensation for damage. In case of the abuse of rights, the most common sanction is the compensation for damage or elimination of the source of risk or danger. On the other hand, return to the previous condition cannot be attained in most cases (Strohsack, 1990: 1169) because the exercise of rights involving abuse is "shrouded" in a subjective right which distinguishes it from an unlawful action" (Marković, 1978: 1012)

The Serbian Ownership and Real Property Relations Act did not completely regulate neighbours' rights, except for the issues pertaining to emissions (private nuisance). The incomplete regulation sometimes gives rise to dilemmas in judicial practice, particularly in terms of whether the specific behaviour constitutes illegal conduct or malicious exercise of rights, a violation of neighbours' rights or an abuse of rights. The judicial practice yielded a number of decisions where the abuse of rights was "mixed" with the violation of neighbours' rights in a manner contrary to explicit legal prohibitions or restrictions on the content of ownership. Basically, the abuse of rights implies a legal restriction of the content of ownership; the restriction is not imposed directly but rather by means of a decision of the court which assesses the permissibility of the goal, or the manner of exercising the right.

In addition to autonomous and independent development of neighbours' rights, the justification for their further expansion was often found in judicial decisions on the abuse of rights. Behaviours that had initially been treated as the abuse of rights were explicitly prohibited over time, attaining the character of neighbourlaw and other forms of restrictions on the content of the ownership right. However, the moment when a specific restriction on the content of ownership is explicitly prescribed by the law, any violation of the specified restriction is treated as unlawful behaviour, not as abuse of rights. The abuse of rights is a more general term that is most frequently regulated by legal standards, which enables the court to adapt the law to the social circumstances in order to ensure the basic 
legal principles: to live honestly, not to offend anyone, and to give everyone what is due. At times, our judicial practice unnecessarily uses the institute of abuse of rights instead of neighbours' ownership restrictions, bit it is sometimes necessary given the absence of legal provision on neighbours' rights.

On the other hand, the abuse of neighbours' rights is possible with those neighbours' rights that provide mutual rights and obligations to the titleholders of ownership rights (e.g. the right to cut overhanging branches and lateral roots growing from the neighbour's tree, or trim overgrown trees overtopping the real estate of the holder of ownership rights, or the right to use the neighbour's real estate for fruit-picking, harvesting or catching a runaway swarm of bees).

It is a known fact that the conditions for using the right to cut branches were set in Roman law, which stipulated that it could be done only if branches lower than 15 feet, as they were considered to be obstructing sunlight, casting a shade over the land and hindering the growth of the neighbour's plants. According to the provision in German law, in order to be cut off, it is required that branches and lateral roots disturb the neighbour (§ 910 BGB al. 2; similarly, art. 687 of the Swiss Civil Code). A similar legal solution is expected to be introduced in the Serbian legislation upon the adoption of the Serbian act on real property rights.

\section{Conclusion}

In addition to the limits explicitly prescribed in statutory legislation regulating the content of ownership and mutual neighbour-law restrictions, ownership and other subjective rights have also been increasingly restricted indirectly, by the purpose of law and the general legal principles and standards of "good practice", "acting in good faith (bona fides)", "public order", "prohibition of abuse of rights", etc.

The prohibition of abuse of rights, as a restriction on exercising the recognised content of the ownership, has been extended from the ownership right into other real property rights (easements, neighbours' rights), and further into other private law areas (law of obligations, succession); over time, its outreach has extended from the sphere of private law into the sphere of public law. Like the sea-god Proteus, it gets transformed into various forms and goes on living in spite of the law and socially accepted morality. Yet, it facilitates the abuse of neighbours' rights, particularly those granting powers to take a positive action on the neighbour's real estate.

The abuse of rights is both a state of affairs (factual legal situation) and a dynamic process. It entails the de facto situation of impermissibility of immoral conduct in exercising one's right as well as the process of ongoing development of 
law in the function of preventing any abnormality in exercising the rights and its permanent socialisation. The prohibition of abuse of right enables the judge to assess the regularity of the manner of exercising the right on the merits of each specific case, bearing in mind the "goal" of the recognised subjective right at the specific time and in the specific society. The prohibition of abuse of rights is aimed at moralization and socialisation of rights, by means of court proceedings and legal standards that enable the law to keep pace with the dynamics of social life changes.

The principle of mutual observance of neighbours' rights transforms neighbours' relations into a legal relationship, imposes sanctions for a violation of envisaged rights, and introduces the element of coercion (enforcement). Neighbour-law restrictions are an expression of "the morality of duty", translated into a direct legal prohibition. In addition to the "morality of duty", the prohibition of abuse of rights additionally expresses "the morality of will", as an expression of victory of the general (public) interest over the individual (private) interest. Good neighbour relations ultimately rest on the exercise of the ownership right and neighbours' rights within the limits of the envisaged legislation and without abuse.

Neighbour-law restrictions on the ownership right are a kind of "prevention" against the abuse of right. Notwithstanding all legislative efforts, any legal concept remains partially indeterminate; the limits of subjective rights cannot be set without raising issues about their content and the likelihood of various abuses by exercising neighbours' rights. The prohibition of abuse of rights is an ongoing process which constantly reasserts the social and cultural elements which, in view of the general (public) interest, call for consideration and civility in exercising one's own right.

The owner's refraining from the abuse of ownership and neighbours' rights is based on the balance of interests of private owners, the fear of reciprocity, and the "authority" of the proverb: "Do not do to others what you do not want to be done to yourself". Thus, the author considers that private property (i.e. privatization) objectively narrows down the "grounds" for the abuse of rights, whereas the development of legal culture narrows down the subjective presumptions of abuse, embodied in amorality and self-centeredness in exercising one's own right. The need to prohibit the abuse of the ownership right and neighbours' rights arises from the fact that positive law cannot fully anticipate and regulate the conduct of individuals in property relations; it is also based on the fact that no legal concept is all-inclusive and comprehensively specified, and that no legal institute is immune to abuse. 


\section{References}

Bogišić, V. (1898). Opšti imovinski zakonik za Knjaževinu Crnu Goru (General Property Code for the Principality of Montenegro), Državna štamparija na Cetinju, 1898; in: (ed.) Danilović, J. (1998). Валтазар Богишић: Општи имовински законик за Књажевину Црну Гору и изабрана дјела (2.издање), Унирекс Подгорица, Службени гласник Београд, 1998.

Gams, A. (1991). Svojina (Ownership), Naučna knjiga, Beograd.

Josserand, L. (1935). Evolucija odgovornosti (Evolution of Responsibility), Branič, Beograd, 7-8, 323-336 (translated by Prof. B. Blagojević).

Jovanović, M. (1996). Da li Gaj i neki drugi svedoče o zloupotrebi prava (Do Gaius and others testify about the abuse of rights?), Zbornik radova Pravnog fakulteta u Nišu, 1996, 78-93.

Konstantinović, M. (1925). Zabrana zloupotrebe prava i socijalizacija prava (Prohibition of abuse of rights and socialisation of rights), Arhiv za pravne i društvene nauke, Beograd, 3/1925, preštampan u Anali Pravnog fakulteta u Beogradu, 1982, vol. 30, br. 3-4 (261-281); https://anali.rs/xml/198-/1982c/19823-4c/Zabrana_zloupotrebe_prava_i_socijalizacija_prava.pdf

Kovačević Kuštrimović, R. (1996). Domen primene načela zabrane zloupotrebe prava (Domain of application of prohibition of abuse of rights), Zbornik sa savetovanja "Zloupotreba prava", Niš, 1996, 17-30.

Kovačević Kuštrimović, R., Lazić, M. (2009). Stvarno pravo (Real Property Law), Punta, Niš.

Lazarević, A. (1960). O zloupotrebi prava i njenome pojmu (On abuse of rights and its concept), Arhiv za pravne i društvene nauke, LXXV, 1960, br. 1-2, 40-57.

Marković, M. (1976). Zloupotreba prava (Abuse of Rights), Enciklopedija imovinskog prava i prava udruženog rada (Encyclopaedia of Property Law and the Law on Associated Labour), Vol. III. BIGZ, Beograd.

Radbruch, G. (1980). Filozofija prava (Legal Philosophy), Nolit, Beograd.

Rodier, R. (1960). Zloupotreba prava (Abuse of Rights), Anali PF u Beogradu, br. 1-2/1960, 1-12..

Savić, S. (2012). Vajmarski Ustav (Weimer Constitution), Zbornik Pravnog fakulteta u Nišu, LX, 2012, 227-234.

Stojčević, D., Romac, A. (1984). Dicta et regulae iuris, Savremena administracija, Beograd. 
Strohsack, B. (1990). Imisije - odnos stvarnopravne i obveznopravne zaštite (Emissions: Relationship between real-law and obligation-law protection), Naša zakonitost, Zagreb, 1990, br. 9-10, 1163-1173.

Stojanović, D. (1987) Stvarno pravo (Real Property Law), Službeni list SFRJ, Beograd.

Stojanović, D. (1991) Pravo svojine u EEZ (The Ownership Right in the EEC), Pravni život, 1991, br. 11-12, 39-58.

Toroman, M. (1978). Susedsko pravo, Enciklopedija imovinskog prava i prava udruženog rada ((Neighbour Law, in Encyclopaedia of Property Law and the Law on Associated Labour), 1978, Vol. III, BIGZ, Beograd,

Legal documents and judicial practice (case law)

French Declaration of the Rights of Man and of the Citizen, 1789, http://www. historyguide.org/intellect/declaration.html

Zakon o osnovama svojinsko-pravnih odnosa Republike Srbije (Act on Ownership and Real Property Relations RS), Službeni list SFRJ, br. 6/1980, 36/1990; Službeni list SRJ, br. 29/1996, i Službeni glasnik RS, br. 115/2005 -dr. zakon.

Zbirka sudskih odluka (Collection of Court Decisions), Beograd, 1969, knj.14, vol. 2, Odluka br. 155

Odluka Višeg suda Vojvodine (Decision of the Higher Court of Vojvodina), Rev. 524/87, Sudska praksa, Beograd, 10/1988, Odluka br. 55 
Др Мирослав Лазић,

Редовни професор Правног факултета,

Универзитет у Нишу

\title{
СУСЕДСКА ПРАВА И ЗЛОУПОТРЕБА ПРАВА
}

\begin{abstract}
Резиме
Рад се бави анализом својине и потребом за њеним ограничењима у приватном и општем интересу. Анализира се однос суседско-правних ограничења и забране злоупотребе права. Суседска права постављају границе у садржини права својине, док забрана злоупотребе права додатно ограничава слободу у вршењу признате садржине права. Сврха рада је да се укаже на основне разлике између суседског права и забране злоупотребе права, али и сродност њихових функција.

Стварна права су апсолутна права која свом титулару гарантују непосредну правну власт на ствари као објекту својине, стварних и личних службености, заложног права и других стварних права. Иако је својина најшире имовинско право, што омогућава читав спектар различитих облика држања, коришћења и располагања, модерно право ограничава власника тако што му намеће обавезу да своја овлашћења врши у складу са друштвено прихватљивим циљем и на друштвено допуштен начин. Овај принщип се потврђује ограничењем својине, али и других стварних права, путем института забране злоупотребе права.

Забрана злоупотребе права није унапред попуњена позитивном садржином већ као један стандард понашања омогућава судији да у сваком конкретном случају процени исправност начина вршења признате садржине стварног права, сагледавањем друштвеног циља субјективног права у одређеном времену и друштву. Забрана (зло)употребе права је израз победе општег над индивидуалним интересом, тако што се спречава „себичност“ и потпуна аутономија у вршењу стварних права која није у складу са ширим, друштвеним интересима.
\end{abstract}

Кључне речи: својина, суседска права, злоупотреба права. 
